\title{
Description of Acoustic and Articulatory Parameters of Vowels in Mapudungun Speakers. Pilot Study
}

\author{
Descripción de Parámetros Acusticos y Articulatorios de las \\ Vocales en Hablantes de Mapudungun. Estudio Piloto \\ Giannina Álvarez; Magaly Ruiz²; Alain Arias ${ }^{1,3,4}$; María Florencia Lezcano ${ }^{1,3}$ \& Ramón Fuentes ${ }^{1,3}$
}

\begin{abstract}
ÁLVAREZ, G.; RUIZ, M.; ARIAS, A.; LEZCANO, M. F. \& FUENTES, R. Description of acoustic and articulatory parameters of vowels in Mapudungun speakers. Pilot study. Int. J. Odontostomat., 14(2):205-212, 2020.

ABSTRACT: Mapudungun is a language used by Mapuche people in some regions of Chile and Argentina. The aim of this study was to describe the vowel phonemes with regard to the articulatory parameters (position of the tongue with respect to the palate and jaw opening) and acoustic parameters (f0, F1, F2 and F3) in Mapudungun speakers in the Region of La Araucanía. The vocalic phonemes of Mapudungun are six, where the first five are similar to those used in Spanish (/a e i o u/), to which is added a sixth vowel (/i//) with its vocalic allophones $(/ \mathrm{i} / /)$ and $[\theta]$. Three Mapudungun speakers were evaluated. The tongue movements were collected by Electromagnetic Articulography $3 \mathrm{D}$ and the data were processed with MATLAB and PRAAT software. It was possible to describe the trajectory of each third of the tongue during the production of the vowels. It was observed that the sixth vowel /ə/ had minimal jaw opening during its pronunciation. In addition, the characteristic of $/ \oslash /$ as an unrounded mid-central vowel was corroborated. In this study, the tongue of mapudungun speakers was in a more posterior position than the found in other studies.
\end{abstract}

PRAAT

KEY WORDS: acoustic phonetics; articulatory phonetics; mapudungun; electromagnetic articulography;

\section{INTRODUCTION}

Mapudungun is a language used by the Mapuche in some regions of Chile and Argentina (Echeverría \& Contreras, 2005; Zúñiga, 2006). For the phonetic study of this language, as well as for the articulatory and acoustic analysis of the voice, the phonemes of Mapudungun can be classified as vowels, semi-vowels and consonants (Zúñiga). In the case of the vowels, there are six vocalic phonemes where the first five are similar to those used in Spanish (/a e i o u/) with identical allophones, to which is added a sixth vowel $(/ \mathrm{i} /$ ) with its vocalic allophones $(/ \mathrm{t} / \mathrm{/})$ and [ə] (Echeverría, 1964; Echeverría \& Contreras; Sadowsky et al., 2013).

Each of these phonemes presents distinctive articulatory features in terms of their vertical dimension (high, mid and low vowels), their horizontal dimension (front, central and back vowels) and whether they are rounded or not rounded in their labialization (Ladefoged, 2001). From this perspective, the phoneme /a/ corresponds to a low central unrounded vowel, the phoneme /e/ is defined as a back mid unrounded vowel, /i/ is a high back unrounded vowel, /o/ is a mid-back rounded vowel and $/ \mathrm{u} /$ is formed as a high back rounded vowel. In the case of $/ \mathrm{i} /$ for its allophones $/ \mathrm{i} /$ and $/ \partial /$, the first is a high back rounded vowel, while the second is a mid-central unrounded vowel (Sánchez Perez \& Salamanca Gutierrez, 2015; Echeverría \& Contreras; Soto-Barba et al., 2016).

In acoustic phonetics, the vowels can be analyzed on the basis of their fundamental frequency, intensity, formants and measures of disturbance like jitter and shimmer, among others (Franca, 2012). The acoustic vowel space can be determined by the area

\footnotetext{
${ }^{1}$ Research Centre for Dental Sciences CICO, Dental School, Universidad de La Frontera, Temuco, Chile.

2 Department of Language, Literature and Communication, School of Education, Social Sciences and Humanities, Universidad de La Frontera, Temuco, Chile

${ }^{3}$ Department of Integral Adults Dentistry, Dental School, Universidad de La Frontera, Temuco, Chile

${ }^{4}$ Research Group of Health Sciences, Universidad Adventista de Chile, Chillán, Chile.

This research is part of the project DFP18-0037
} 
defined by F2 and F1 (Weirich \& Simpson, 2013) and is used to represent the relative positions of the tongue, in both its height and front-back advancement during vowel production (Sun et al., 2013; Wang et al., 2013). Although the phonetic and acoustic analysis of Mapudungun has made progress, the articulatory characteristics have scarcely been explored. Therefore, the aim of this exploratory study was to describe the vowel phonemes with regard to the articulatory parameters (position of the tongue with respect to the palate and jaw opening) and acoustic parameters (fundamental frequency and first three formants) in Mapudungun speakers in the Region of La Araucanía.

\section{MATERIAL AND METHOD}

Participants: In this preliminary study, acoustic data and tongue movement (articulatory) data were recorded in three Mapudungun speakers ( 2 men and 1 woman), with an average age of $26.3 \pm 4$ years (Table I). All the participants signed the respective informed consent to take part in the study, which was approved by the Scientific Ethics Committee of the Universidad de La Frontera (Protocol № 125/18). The speakers had full dentition with permanent teeth (up to the first molar), occlusal stability and no respiratory problems or morphofunctional alterations of speech, voice or hearing.

The participants are speakers from the province of Cautin, Region the La Araucanía, bilingual, whose mother tongue is Spanish (L1) and who received formal or informal instruction in Mapudungun during their childhood. All the speakers in this study use Mapudungun (L2) on a regular basis to communicate in their family unit and are recognized in their communities for their proficiency in and teaching of this language.

Electromagnetic articulography (EMA 3D): The acoustic data and tongue movement, its relation with the palate and jaw opening, were simultaneously recorded during the articulation of the vowels in Spanish and Mapudungun: /i/, /e/, /a/, /o/, / / /, /O/. The 3D AG501 electromagnetic articulograph (Carstens Medizinelektronik, Bovenden, Germany) was used, which has suitable spatial resolution (margin of error $0.3 \mathrm{~mm}$ ) and temporal resolution (sampling frequency to 250 Hertz) to record and analyze articulatory movements (Steele \& Van Lieshout, 2004; Fuentes et al., 2017). Eight sensors from the articulograph were attached with a tissue adhesive (Epiglu $\circledast$, Meyer-Haake, Germany) to different specific points on each participant's head and oral cavity: skin point of the right (1) and left mastoid (2), glabella (3); those on the back of the tongue in its anterior (4), middle (5) and posterior third (6) were positioned according to previous protocols (Chen et al., 2015; Álvarez et al., 2019), mandibular inter-incisor midline (7) and an extra sensor attached to a wooden rod to record the midsagittal profile of the palate (8) (Toutios et al., 2011; Álvarez et al.,). The three first sensors were used as a benchmark to standardize the position data for the remaining sensors (4 to 7 ) and thus eliminate the natural movement of the head from the records.

Once the sensors had been placed, and to begin the vowel recordings, the participants were seated under the transmitter coils of the articulograph in an upright, comfortable position facing front.

Audio recording: At the same time as the articulatory movement was recorded, a voice recording (.wav format) was made using the system incorporated into the articulograph, which includes an ALESIS i02 portable audio interface with a t-bone EM 9600 unidirectional microphone (frequency range $60 \mathrm{~Hz}-18 \mathrm{KHz}$ ) placed $30 \mathrm{~cm}$ from the participant's mouth.

Recording procedure: Prior to the recording session with each participant, each was asked to remove any metallic elements and electronic devices they had on them (to avoid interference with the equipment). Each participant was instructed on the activities to perform during the measurement, and training was done to become familiar with the presence of the sensors on the tongue, (first without the sensors and then with the sensors positioned on the tongue) consisting of breathing exercises, swallowing saliva, articulation of the vowel phonemes and four specific words (atraso angosto - pantruca - angina). These training words were selected for having: a) three syllables, b) accent on the penultimate syllable (paroxytone words) and c) stressed syllables joined as CCV (consonant, consonant, vowel) or CVC (consonant, vowel, consonant).

Thus the following records were made:

i) Record of the midsagittal profile of the palate, positioning the sensor of the wooden rod at the base of the participant's uvula to then advance forward from the soft and hard palate, via the midline, until arriving at the incisive papilla.

ii) Record of the maximum intercuspation position (MIP) to define a starting point with dental contact between 
the mandible and the maxilla. Thus it was possible to determine the width of the jaw opening when pronouncing each vowel.

iii) Record of the vowel phonemes (/a/, /e/, /i/, /o/, /u/, $/ \partial /)$. For this, an operator instructed the participant to pronounce each vowel one by one and maintain it for at least 2 seconds with a tone of voice they usually use. There were three repetitions per phoneme and the most intelligible one was selected for the analysis.

Data processing: The MATLAB® (MathWorks Inc., USA) software was used to process the position data (articulatory movements) obtained with the articulograph. With this software it was possible to generate specific calculation routines or processing scripts and thus to collect quantitative data on the movement of the tongue in its three thirds (anterior, middle and posterior) and of the jaw in the sagittal plane (superior - inferior). Also, the shape and dimension of the palate was obtained to calculate the area (in $\mathrm{mm}^{2}$ ) of the sub-palatal space in the sagittal plane. For this study it was defined as the area between the sub-palatal space and the straight line that joins the first and last point of the palate delimitation record (between the base of the uvula and incisive papilla). It was also possible to create trajectory diagrams of the lingual thirds and jaw relative to the palate with the software.

The PRAAT free software was used to process the voice records (Boersma and Weenink, Amsterdam, 2018). Thus, an acoustic analysis was performed of the fundamental frequency, formants and acoustic vowel space for each vowel pronounced.

\section{RESULTS}

The size of the sub-palatal space is itemized in Table I, where, by calculating the area in the midsagittal plane, a reference of the height of the palate with respect to its front and back edges was obtained. On this point, the highest observed value was $939.5 \mathrm{~mm}^{2}$ for speaker
$\mathrm{N} 1$, and the lowest observed value was $636.4 \mathrm{~mm}^{2}$ for speaker N3, both men. In the same table (Table I), the residential area (urban or rural) is indicated.

Table II provides the values (in $\mathrm{mm}$ ) of the maximum jaw opening for each of the vowels in the three participants. This value was calculated in relation to the MIP record, with the highest value being for the vowel la/ of participant N1 $(11.09 \mathrm{~mm})$ and the lowest value for the vowel / / of participant N2 (1.86 mm). Additionally, the distances or maximum and minimum separation (in $\mathrm{mm}$ ) of each lingual third (anterior, middle and posterior) relative to the palate during the vocalization sequence of the three participants are shown. The greatest distance for the anterior third of the tongue was during the articulation of the vowel /o/ and it was $32.11 \mathrm{~mm}$, for the middle third of the tongue language it was during the articulation of the vowel /o/ and it was $32.56 \mathrm{~mm}$, while for the posterior third of the tongue it was during the articulation of the vowel /u/ and it was $28.66 \mathrm{~mm}$, all of them in participant N1. On the other hand, the smallest distance for the anterior third was during the articulation of the vowel /u/ and it was $0.49 \mathrm{~mm}$, for the middle third it was during the articulation of the vowel /i/ and it was $0.00 \mathrm{~mm}$ (tongue in direct contact with the palate), while for the posterior third it was during the articulation of all the vowels with the exception of the vowel /a/ and it was $0.01 \mathrm{~mm}$ in all those cases. All these values were in participant $\mathrm{N} 2$.

Figure 1 presents the means of the jaw displacements (in $\mathrm{mm}$ ) relative to starting point or MIP, where a trend is observed of greater jaw opening for the vowel /a/ and smaller jaw opening for the vowel / $\partial$. The same chart also shows the mean of the minimum and maximum distances of the lingual thirds relative to the palate, where it is possible to note a tendency towards greater descent of the tongue for the anterior third (with average maximum distances greater than the other thirds) and a smaller distance or separation relative to the palate (greater contact with the palate) for the posterior third.

Figure 2 provides an example of the trajectory

Table I. Characteristics of the study participants.

\begin{tabular}{ccccccc}
\hline Participant & Sex & $\begin{array}{c}\text { Age } \\
\text { (years) }\end{array}$ & L1 & L2 & $\begin{array}{c}\text { Area of } \\
\text { residence }\end{array}$ & $\begin{array}{c}\text { Sagittal area of } \\
\text { the sub-palatal } \\
\text { space }(\mathrm{mm})^{2}\end{array}$ \\
\hline N1 & Male & 24 & Spanish & Mapudungun & Rural & 939.5 \\
N2 & Female & 31 & Spanish & Mapudungun & Urban & 815.6 \\
N3 & Male & 24 & Spanish & Mapudungun & Rural & 636.4 \\
\hline
\end{tabular}


ÁlVAREZ, G.; RUIZ, M.; ARIAS, A.; LEZCANO, M. F. \& FUENTES, R. Description of acoustic and articulatory parameters of vowels in Mapudungun speakers. Pilot study. Int. J. Odontostomat., 14(2):205-212, 2020.

Table II. Width of the jaw opening $(\mathrm{mm})$ relative to the MIP and minimum and maximum distances (separation) of the lingual thirds (anterior, middle and posterior) in millimeters relative to the palate during the articulation of each vowel.

\begin{tabular}{|c|c|c|c|c|c|c|c|c|}
\hline Vowel & Participant & $\begin{array}{c}\text { Jaw } \\
\text { opening }\end{array}$ & $\begin{array}{l}\text { Tongue } \\
\text { anterior } \\
\text { third min } \\
(\mathrm{mm})\end{array}$ & $\begin{array}{l}\text { Tongue } \\
\text { anterior } \\
\text { third max } \\
(\mathrm{mm})\end{array}$ & $\begin{array}{l}\text { Tongue } \\
\text { middle } \\
\text { third min } \\
(\mathrm{mm})\end{array}$ & $\begin{array}{l}\text { Tongue } \\
\text { middle } \\
\text { third max } \\
(\mathrm{mm})\end{array}$ & $\begin{array}{l}\text { Tongue } \\
\text { posterior } \\
\text { third min } \\
(\mathrm{mm})\end{array}$ & $\begin{array}{c}\text { Tongue } \\
\text { posterior } \\
\text { third max } \\
(\mathrm{mm})\end{array}$ \\
\hline \multirow{3}{*}{ lal } & N1 & 11.09 & 5.91 & 26.28 & 9.18 & 27.45 & 6.04 & 16.67 \\
\hline & N2 & 6.90 & 8.40 & 20.75 & 4.63 & 11.17 & 2.52 & 5.43 \\
\hline & N3 & 8.08 & 3.66 & 17.39 & 0.55 & 13.26 & 2.31 & 12.20 \\
\hline \multirow{3}{*}{ lel } & $\mathrm{N} 1$ & 7.17 & 6.64 & 14.81 & 11.65 & 14.14 & 6.15 & 8.80 \\
\hline & N2 & 4.64 & 7.65 & 12.07 & 0.27 & 3.48 & 0.01 & 4.84 \\
\hline & N3 & 9.17 & 2.63 & 15.80 & 0.97 & 6.24 & 1.92 & 11.64 \\
\hline \multirow{3}{*}{ /i/ } & N1 & 4.38 & 8.07 & 12.08 & 8.09 & 14.06 & 3.63 & 10.33 \\
\hline & N2 & 5.53 & 4.87 & 11.57 & 0.00 & 2.17 & 0.02 & 5.93 \\
\hline & N3 & 6.55 & 2.37 & 12.61 & 1.05 & 5.46 & 3.04 & 13.74 \\
\hline \multirow{3}{*}{ lol } & N1 & 7.27 & 8.94 & 32.11 & 18.44 & 32.56 & 12.60 & 19.58 \\
\hline & N2 & 6.27 & 13.10 & 21.58 & 6.80 & 12.42 & 0.01 & 3.83 \\
\hline & N3 & 5.13 & 2.47 & 20.11 & 3.51 & 12.20 & 0.42 & 7.50 \\
\hline \multirow{3}{*}{$/ \mathrm{u} /$} & N1 & 3.22 & 4.89 & 19.32 & 14.86 & 25.46 & 18.86 & 28.66 \\
\hline & N2 & 5.77 & 0.49 & 19.52 & 3.67 & 7.70 & 0.01 & 3.43 \\
\hline & N3 & 5.58 & 1.24 & 23.18 & 0.08 & 11.71 & 0.02 & 7.84 \\
\hline \multirow{3}{*}{ /ӨI } & N1 & 4.94 & 6.72 & 12.72 & 14.78 & 24.78 & 5.60 & 11.68 \\
\hline & N2 & 1.86 & 9.97 & 14.04 & 2.90 & 6.93 & 0.01 & 5.28 \\
\hline & N3 & 4.16 & 1.35 & 24.42 & 0.15 & 18.19 & 0.85 & 8.45 \\
\hline
\end{tabular}

30,00

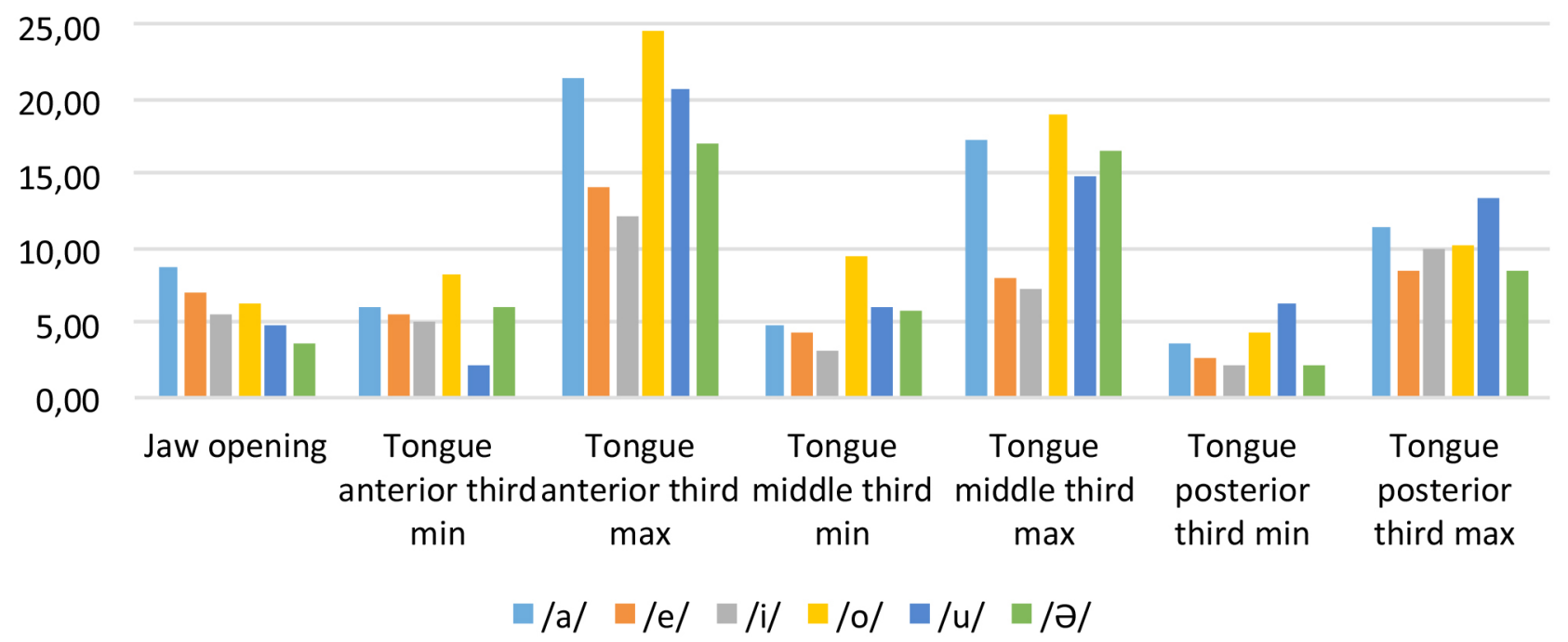

Fig. 1. Diagram with the displacement (in $\mathrm{mm}$ ) of the open jaw and distances to the palate ( $\mathrm{mm}$ ) of the tongue thirds during the vocalization of /i/, /e/, /a/, /o/, /u/, /ə/. 
in the sagittal plane of the sensor placed on the jaw and of the sensors placed on the anterior, middle and posterior thirds of the tongue in participant N1 during
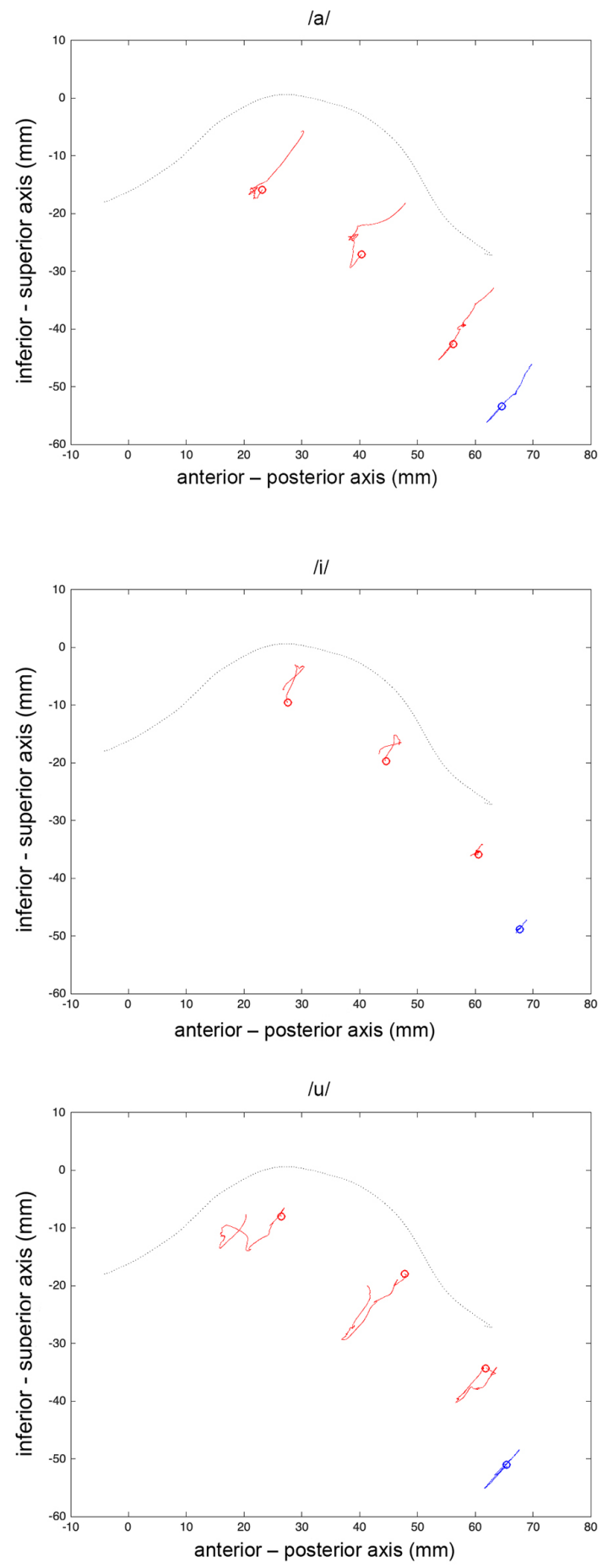

the vocalization of $/ \mathrm{a} /, / \mathrm{e} /, \mathrm{li} /, / \mathrm{o} /, / \mathrm{u} /, / \partial /$. Note that for the case of $/ a /$, there is a drop in the central position of the lingual thirds, accompanied by the jaw opening. In the
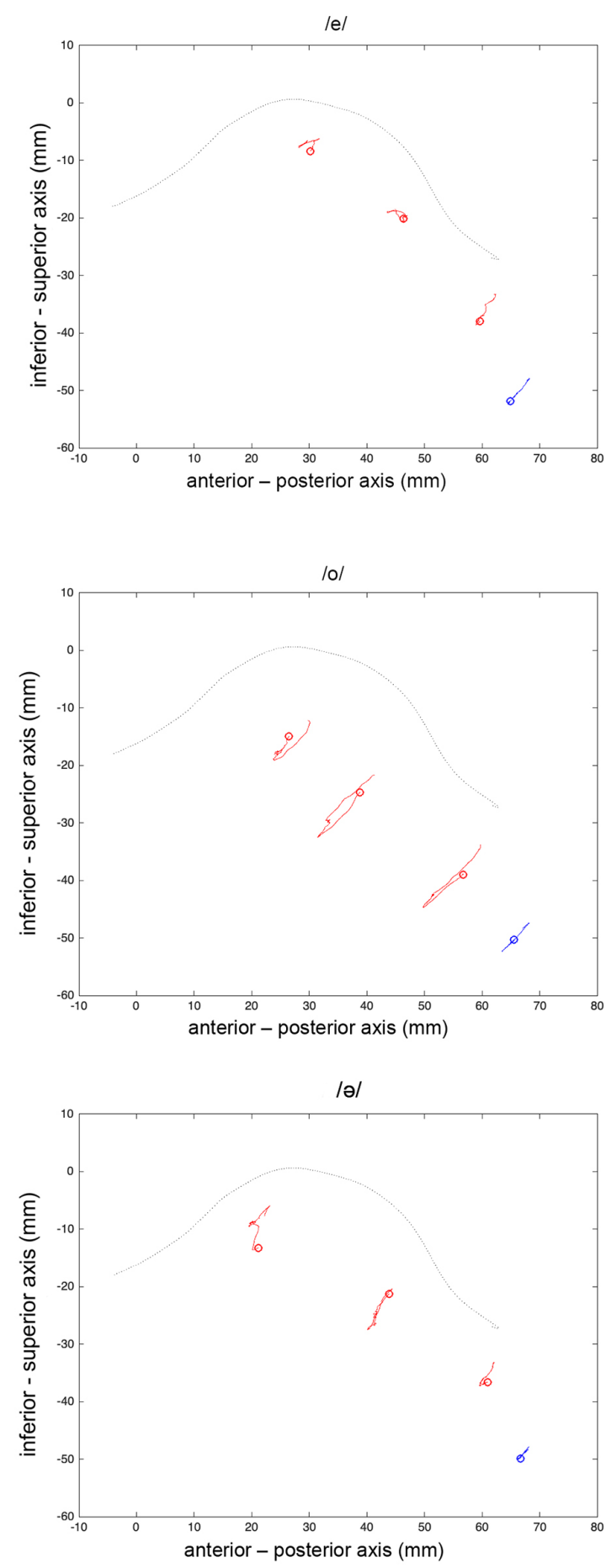

Fig. 2. Position diagram with the trajectory in the sagittal plane (superior-inferior and posterior-anterior axis) of the sensors located in the anterior, middle, and posterior thirds of the tongue (red lines), the sensor of the jaw (blue line) and the sagittal profile of the palate (dashed black line) of one of the participants (N1) during the vocalization of /a/, /e/, /i/, /o/, /u/, /ə/. The circle indicates the initial position of the sensor during the recording. 
case of /e/, there is a minimal drop of the anterior third accompanied by a similar drop of the jaw, a backward advancement of the middle third and a slight rise of the posterior third. For /i/, close contact of the middle and posterior thirds with the palate is observed, with a marked upward and forward displacement and a slight drop of the anterior third similar to the downward displacement of the jaw. In this case, contact with the palate is noted by the demarcation and limitation in the movement that the sensors present, but graphically this contact is not faithfully observed due to the size of the sensor ( $3 \mathrm{~mm}$ ), whose movement recording is given from its center. In the case of /o/ the displacement is downward, similar to that of the /a/ vowel but towards a posterior position, whereas the jaw drop is slight, not accompanying the greatest width that the sensors show of the anterior and middle thirds. In the case of $/ u /$, a similar drop and rise of the anterior lingual third and the jaw is observed, a noticeable downward and upward displacement of the middle third and an upward and backward displacement of the posterior third. Finally, for / $/$ / a slight drop in the anterior third, posterior third and the jaw is observed, and a large drop in the middle third.

Regarding the data collected of the base frequencies (f0) and the formants F1, F2 and F3, Table III shows the values for each vowel individually per participant. For f0, the greatest value found was 204
$\mathrm{Hz}$ during the articulation of the /u/ vowel by participant $\mathrm{N} 2$, whereas the smallest value found was $105.5 \mathrm{~Hz}$ during the articulation of the /a/ vowel by participant N3. For F1, which indicates the height of the tongue, the greatest value found was $728 \mathrm{~Hz}$ for the articulation of the /a/ vowel by participant N2, whereas the smallest value found was $289.2 \mathrm{~Hz}$ for the articulation of the /i/ vowel by participant N3. With respect to F2, which indicates the anterior-posterior position of the tongue, the greatest value was $2532 \mathrm{~Hz}$ for the articulation of the /i/ vowel by participant N2, whereas the lowest value was $849 \mathrm{~Hz}$ for the articulation of the /u/ vowel by participant N1. Finally, for F3, which informs on the roundedness of the lips, the highest value was 3312 $\mathrm{Hz}$ for the articulation of the /a/ vowel by participant $\mathrm{N} 2$, whereas the smallest value was $2556 \mathrm{~Hz}$ for the articulation of the /e/ and /ə/ vowels by participant N3.

Figure 3 presents the diagram of the acoustic vowel space obtained from the values of $\mathrm{F} 1$ and $\mathrm{F} 2$ of the vowels /a, e, i, o, u, $\partial$ / for the three Mapudungun speakers. In the scheme obtained, there is a certain variability among the speakers, with the female speaker (N2) being the one who moves away at some points from the other speakers. With her, there was a lower tongue height and pharyngeal narrowing like a greater anteriorization of the tongue for all the vowels compared to the other speakers, which translates into higher frequencies in the emission of the vowels.

Table III. Values in Hertz of the fundamental frequency and the three first formants for each vowel.

\begin{tabular}{cccccc}
\hline Vowel & Participant & $\mathrm{f} 0(\mathrm{~Hz})$ & $\mathrm{F} 1(\mathrm{~Hz})$ & $\mathrm{F} 2(\mathrm{~Hz})$ & $\mathrm{F} 3(\mathrm{~Hz})$ \\
\hline \multirow{3}{*}{ /a/ } & $\mathrm{N} 1$ & 125.3 & 679.3 & 1411.0 & 2654.0 \\
& $\mathrm{~N} 2$ & 174.3 & 728.0 & 1459.0 & 3312.0 \\
& $\mathrm{~N} 3$ & 105.5 & 654.9 & 1264.0 & 2581.0 \\
/e/ & $\mathrm{N} 1$ & 119.7 & 459.9 & 1825.0 & 2629.0 \\
& $\mathrm{~N} 2$ & 184.9 & 459.0 & 2337.0 & 2873.0 \\
& $\mathrm{~N} 3$ & 112.3 & 435.0 & 2093.0 & 2556.0 \\
li/ & $\mathrm{N} 1$ & 121.7 & 362.4 & 2191.0 & 2702.0 \\
& $\mathrm{~N} 2$ & 185.1 & 435.5 & 2532.0 & 2971.0 \\
& $\mathrm{~N} 3$ & 122.0 & 289.2 & 2410.0 & 2849.0 \\
Io/ & $\mathrm{N} 1$ & 125.8 & 484.2 & 874.3 & 2824.0 \\
& $\mathrm{~N} 2$ & 190.0 & 557.4 & 1142.0 & 3214.0 \\
& $\mathrm{~N} 3$ & 108.4 & 533.0 & 947.0 & 2581.0 \\
/u/ & $\mathrm{N} 1$ & 127.4 & 411.1 & 849.0 & 2751.0 \\
& $\mathrm{~N} 2$ & 204.0 & 435.0 & 1094.0 & 3044.0 \\
& $\mathrm{~N} 3$ & 120.5 & 386.0 & 898.0 & 2629.0 \\
/ə/ & $\mathrm{N} 1$ & 126.0 & 435.5 & 1216.0 & 2727.0 \\
& $\mathrm{~N} 2$ & 175.6 & 435.5 & 1289.0 & 2971.0 \\
& $\mathrm{~N} 3$ & 108.5 & 459.9 & 1240.0 & 2556.0 \\
\hline
\end{tabular}




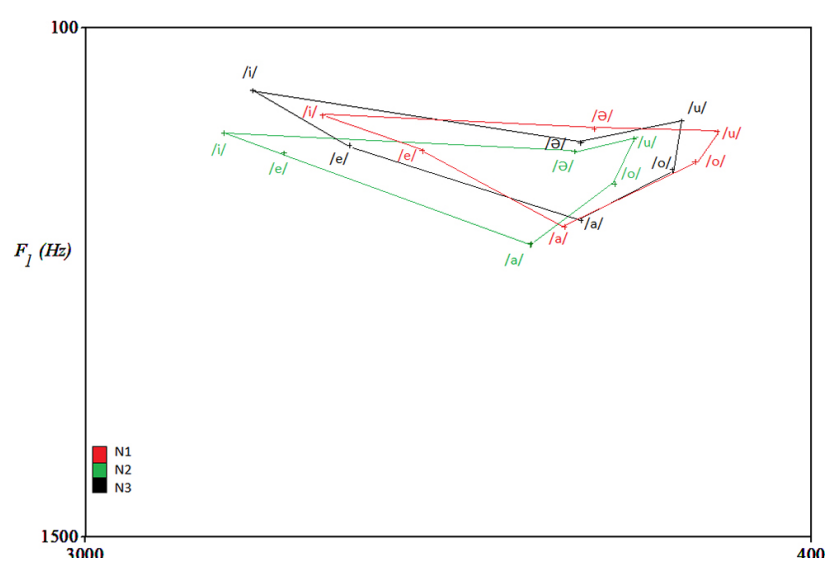

Fig. 3. Acoustic vowel space, defined by the values of formants F1 x F2 of the vowels /i/, /e/, /a/, /o/, /u/, /ə/ for the three Mapudungun speakers.

\section{DISCUSSION}

The aim of our study was to describe the vowel phonemes in terms of articulatory and acoustic parameters in Mapudungun speakers.

Electromagnetic articulography was used to do this because it enables a suitable characterization of the tongue movement and jaw opening during the production of the vowel sounds. This technique has been widely used in phonetics and linguistics (Wang et al., 2009, 2013; Meenakshi et al., 2014; Lee et al., 2017), and in this case it gave us relevant data regarding the interaction of the tongue and palate, both from the charted trajectory of the tongue (in its anterior, middle and posterior thirds) as well as from the quantitative data of the distance of each lingual third to the palate. In the literature it is possible to find different studies that consider the position of the palate and the tongue in the production of sound (Ishida et al., 2002; Toutios et al.; Noiray et al., 2014); however, to the best of our understanding it was not possible to find studies that mention an analysis with the minimum and maximum distances to the palate or to the jaw opening, which is why this study contributes new information and a reliable and replicable methodology for other analyses.

The area of the sub-palatal space must be addressed in a broader sample to identify whether it significantly correlates with the displacement of the tongue and the values of the formants. In this case, a larger sub-palatal area was observed in one of the participants, who simultaneously presented greater values of distance of the tongue to the palate in general. The literature describes the anatomical characteristics of the vocal tract as being able to influence the production of sounds (Rendall et al., 2005).

With respect to the acoustic analysis, the values obtained for the Mapudungun vowels may be comparable to the data collected by other authors for the vowels in Spanish and for the sixth Mapudungun vowel. On this point, we can mention that Sadowsky et al., performed a standardization of the mean values of the formants for $/ \partial /$ and its respective allophones, finding for this vowel average $\mathrm{F} 1$ values of $360 \mathrm{~Hz}$ and F2 values of $1480 \mathrm{~Hz}$ in the Huapi Island sector in the Chile's Region of La Araucanía (Sadowsky et al.,; Soto-Barba et al.,). Meanwhile, in the study by Soto-Barba et al., for the analysis of $/ \Theta /$ conducted on speakers in the Bío-Bío and Queuco sectors, Alto Bío-Bío, Chile, they found that the mean of $\mathrm{F} 1$ for each sector was $505 \mathrm{~Hz}$ and $475 \mathrm{~Hz}$ respectively, whereas for $\mathrm{F} 2$ it was $1417 \mathrm{~Hz}$ and 1350 $\mathrm{Hz}$ respectively (Soto-Barba et al.,). In our findings, the $\mathrm{F} 1$ mean /O/ was $444 \mathrm{~Hz}$, a value near that reported by Soto-Barba et al., in the Queuco sector (Soto-Barba et al.,). The F2 mean was $1248 \mathrm{~Hz}$ in our sample, lower than that described by other authors, which would indicate a less anterior position of the tongue than expected. With respect to the other vowels, a study of the vowels in Spanish speakers in Santiago de Chile (Díaz et al., 2015) indicates higher average fundamental frequency values for men and women than those found in this study for all the vowels. In the same study, the F1 values described for the men were similar or slightly lower than those found in our study; however, in the case of the women, the F1 described here from the female speaker was slightly higher for the extreme vowels /a/, /i/, /u/. In relation to F2, for the vowels /a/, /e/ and /i/, the values described in our study were similar or slightly lower than those reported by Díaz et al., whereas for $/ 0 /$ and $/ u /$, the F2 values described in our study are much lower, with a mean of $1431 \mathrm{~Hz}$ and $1440 \mathrm{~Hz}$ respectively for each vowel. This indicates that in the Mapudungun speakers included in this study, the tongue is in a more posterior position than expected. In the case of $\mathrm{F} 3$, the values of the Mapudungun speakers were similar or slightly lower for all the vowels compared to the data found by Díaz et al., In the work carried out by Catalán (2012), the values of formants F1 and F2 for the Mapudungun vowels are presented, values similar to those in our study for $F 2$ in men and women, but generally with lower values for $F 1$ than found in our study.

This study provides objective and novel data about the articulatory analysis of the vowels of Mapudungun, complementing the information published to date 
on the acoustic data and contributing a novel methodology for their study. However, one of its limitations is the difficulty of accessing participants who speak the language. To continue this line of enquiry, it would be interesting to study the consonants and the coarticulation of vowels and both stressed and unstressed consonants in this language. Future research should assess the articulatory and acoustic parameters of Mapudungun speakers in the Region of La Araucanía and include the participation of other anatomical structures in the production of sound in the analysis.

ACKNOWLEDGEMENTS. This research is part of the project DFP18-0037 and this work was (partially) financed by the Research Office, Universidad de La Frontera.

ÁlVAREZ, G.; RUIZ, M.; ARIAS, A.; LEZCANO, M. F. \& FUENTES, R. Descripción de parámetros acusticos y articulatorios de las vocales en hablantes de mapudungun. Estudio piloto. Int. J. Odontostomat., 14(2):205-212, 2020.

RESUMEN: El Mapudungun es un lenguaje utilizado por los mapuches en algunas regiones de Chile y Argentina. El objetivo de este estudio fue describir los fonemas vocálicos respecto a los parámetros articulatorios (posición de la lengua respecto al paladar y apertura mandibular) y los parámetros acústicos (f0, F1, F2 y F3) en hablantes de Mapudungun en la Región de La Araucanía, los fonemas vocálicos de Mapudungun son seis, donde los primeros cinco son similares a los utilizados en español (/a e i o u /), a los que se agrega una sexta vocal (///) con sus alófonos vocálicos [i] y $[\partial]$. Se evaluaron tres hablantes de Mapudungun. Los movimientos de la lengua fueron registrados por Articulografía Electromagnética $3 D$ y los datos fueron procesados con el software MATLAB y PRAAT. Fue posible describir la trayectoria de cada tercio de la lengua durante la producción de las vocales. Se observó que la sexta vocal /ə/ tenía una apertura mínima de la mandíbula durante su pronunciación. Además, se corroboró la característica de /Ө/ como vocal central media no redondeada. En este estudio, la lengua de los hablantes de mapudungun estaba en una posición más posterior que la encontrada en otros estudios.

PALABRAS CLAVE: fonética acústica, fonética articular, Mapudungun, articulografía electromagnética, PRAAT.

\section{REFERENCES}

Álvarez, G.; Dias, F. J.; Lezcano, M. F.; Arias, A. \& Fuentes, R. A novel three-dimensional analysis of tongue movement during water and saliva deglutition: a preliminary study on swallowing patterns. Dysphagia, 34(3):397-406, 2019

Catalán, R. Estudio Fonético Acústico de las Vocales del Mapudungun. Master's thesis. Santiago de Chile, Universidad Católica de Chile, 2012.

Chen, W. R.; Chang, Y. C.; \& Iskarous, K. Vowel coarticulation: landmark statistics measure vowel aggression. J. Acoust. Soc. Am., 138(2):1221-32, 2015.

Díaz, A. S.; Cisternas, L. P. \& López, B. I. Características acústicas de las vocales del español de Chile producidas por sujetos residentes en la ciudad de Santiago. Rev. Chil. Fonoaudiol., 14:92-102, 2015.

Echeverría, M. S. \& Contreras, H. Araucanian phonemics. Int. J. Am. Linguist.,
31(2):132-5, 2005.

Echeverría, M. S. Descripción fonológica del mapuche actual. Bol. Filol. Univ. Chile, 16:13-59, 1964.

Franca, M. C. Acoustic comparison of vowel sounds among adult females. J. Voice, 26(5):671.e9-17, 2012.

Fuentes, R.; Arias, A.; Saravia, D.; Lezcano, M. F. \& Dias, F. J. An innovative method to analyse the range of border mandibular movements using $3 D$ electromagnetic articulography (AG501) and MATLAB. Biomed. Res. (India), 28(9):4239-47, 2017.

Ishida, R.; Palmer, J. B. \& Hiiemae, K. M. Hyoid motion during swallowing: factors affecting forward and upward displacement. Dysphagia, 17(4):26272, 2002.

Ladefoged, P. Vowels and Consonants?: An Introduction to the Sounds of Languages. Oxford, Wiley-Blackwell, 2001.

Lee, J.; Littlejohn, M. A. \& Simmons, Z. Acoustic and tongue kinematic vowel space in speakers with and without dysarthria. Int. J. Speech Lang. Pathol., 19(2):195-204, 2017.

Meenakshi, N.; Yarra, C.; Yamini, B. K. \& Ghosh, P. K. Comparison of speech quality with and without sensors in electromagnetic articulograph AG 501 recording. Singapore, INTERSPEECH. 15th Annual Conference of the International Speech Communication Association, 2014. pp.935-9.

Noiray, A.; Iskarous, K. \& Whalen, D. H. Variability in english vowels is comparable in articulation and acoustics. Lab. Phonol., 5(2):271-88, 2014.

Rendall, D.; Kollias, S.; Ney, C. \& Lloyd, P. Pitch (F0) and formant profiles of human vowels and vowel-like baboon grunts: the role of vocalizer body size and voice-acoustic allometry. J. Acoust. Soc. Am., 117(2):944-55, 2005.

Sadowsky, S.; Painequeo, H.; Salamanca, G. \& Avelino, H. Mapudungun. J. Int. Phon. Assoc., 43(1):87-96, 2013.

Sánchez Perez, M. A. \& Salamanca Gutierrez, G. F. El mapuche hablado en Lonquimay: Fonemas segmentales, fonotaxis y comparación con otras variedades. Lit. Lingüíst., (31):295-334, 2015.

Soto-Barba, J.; Lara, I. \& Salamanca, G. Descripción fonético-acústica de la sexta vocal en el chedungun hablado en Alto Bío-Bío. Onomazein, 34:229-41, 2016

Steele, C. M. \& Van Lieshout, P. H. H. M. Use of electromagnetic midsagittal articulography in the study of swallowing. J. Speech Lang. Hear. Res., 47(2):342-52, 2004.

Sun, J.; Yan, N. \& Wang, L. Constructing a Three-Dimension Physiological Vowel Space of the Mandarin Language using Electromagnetic Articulography. Kaohsiung, 2013 Asia-Pacific Signal and Information Processing Association Annual Summit and Conference, APSIPA, 2013.

Toutios, A.; Ouni, S. \& Laprie, Y. Estimating the control parameters of an articulatory model from electromagnetic articulograph data. J. Acoust. Soc. Am., 129(5):3245-57, 2011.

Wang, J.; Green, J. R.; Samal, A., \& Yunusova, Y. Articulatory distinctiveness of vowels and consonants: a data-driven approach. J. Speech Lang. Hear. Res., 56(5):1539-51, 2013.

Wang, J.; Samal, A.; Green, J. R. \& Carrell, T. D. Vowel Recognition from Articulatory Position Time-Series Data. Omaha, 3rd International Conference on Signal Processing and Communication Systems, 2009.

Weirich, M. \& Simpson, A. Investigating the relationship between average speaker fundamental frequency and acoustic vowel space size. J. Acoust. Soc. Am., 134(4):2965-74, 2013.

Zúñiga, F. Mapudungun. El Habla Mapuche. Santiago de Chile, Centro de Estudios Públicos, 2006. Available from: https://www.cepchile.cl/cep/site/ artic/20160304/asocfile/20160304094227/libro_Mapudungun_Fernando-Zuniga.pdf

Corresponding author

Prof. Dr. Ramón Fuentes Fernández

Research Centre for Dental Sciences CICO

Dental School

Universidad de La Frontera

Av. Francisco Salazar 01145

Temuco-CHILE

Received: 25-11-2019

Accepted: 06-01-2020

E-mail: ramon.fuentes@ufrontera.cl 